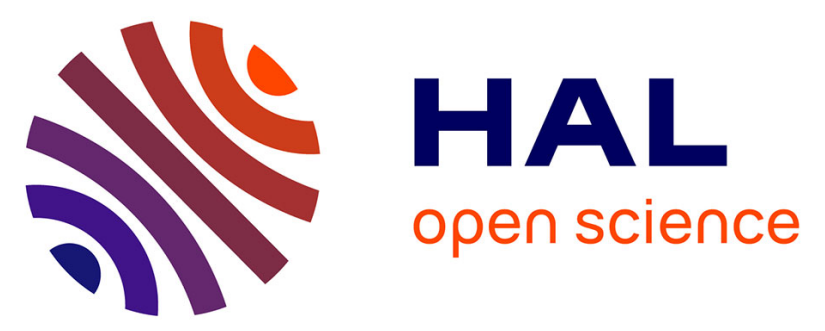

\title{
Geochemical and sulfate isotopic evolution of flowback and produced waters reveals water-rock interactions following hydraulic fracturing of a tight hydrocarbon reservoir
}

Florian Osselin, S. Saad, M. Nightingale, G. Hearn, M. Desaulty, E.C. Gaucher, C.R. Clarkson, Wolfram Kloppmann, B. Mayer

\section{To cite this version:}

Florian Osselin, S. Saad, M. Nightingale, G. Hearn, M. Desaulty, et al.. Geochemical and sulfate isotopic evolution of flowback and produced waters reveals water-rock interactions following hydraulic fracturing of a tight hydrocarbon reservoir. Science of the Total Environment, 2019, 687, pp.1389-1400. 10.1016/j.scitotenv.2019.07.066 . insu-02270202

\section{HAL Id: insu-02270202}

\section{https://hal-insu.archives-ouvertes.fr/insu-02270202}

Submitted on 1 Apr 2020

HAL is a multi-disciplinary open access archive for the deposit and dissemination of scientific research documents, whether they are published or not. The documents may come from teaching and research institutions in France or abroad, or from public or private research centers.
L'archive ouverte pluridisciplinaire HAL, est destinée au dépôt et à la diffusion de documents scientifiques de niveau recherche, publiés ou non, émanant des établissements d'enseignement et de recherche français ou étrangers, des laboratoires publics ou privés.

\section{(ㄷ)(1) $(2$}

Distributed under a Creative Commons Attribution - NonCommerciall 4.0 International 


\title{
Geochemical and sulfate isotopic evolution of flowback and produced waters reveals water-rock interactions following hydraulic fracturing of a tight hydrocarbon reservoir
}

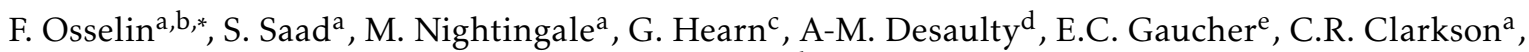 \\ W. Kloppmann ${ }^{\text {d }}$, B. Mayer ${ }^{\mathrm{a}}$ \\ ${ }^{a}$ Department of Geoscience, University of Calgary, 2500 University Drive, Calgary, Alberta, Canada T2N 1N4 \\ ${ }^{b}$ Institut des Sciences de la Terre d'Orléans, 1 A Rue de la Ferollerie, 45100 Orléans, France \\ ${ }^{c}$ Seven Generations Energy, 101,9601 - 113 St. Grande Prairie, Alberta, Canada T8V 6H2 \\ ${ }^{d}$ BRGM, French Geological Survey, 2 Avenue Claude Guillemin, BP 6009, 45060 Orléans CEDEX 2, France \\ ${ }^{e}$ TOTAL CSTJF, Avenue Larribau, Pau F-64000, France
}

\begin{abstract}
Although multistage hydraulic fracturing is routinely performed for the extraction of hydrocarbon resources from low permeability reservoirs, the downhole geochemical processes linked to the interaction of fracturing fluids with formation brine and reservoir mineralogy remain poorly understood. We present a geochemical dataset of flowback and produced water samples from a hydraulically fractured reservoir in the Montney Formation, Canada, analyzed for major and trace elements and stable isotopes. The dataset consists in 25 samples of flowback and produced waters from a single well, as well as produced water samples from 16 other different producing wells collected in the same field. Additionally, persulfate breaker samples as well as anhydrite and pyrite from cores were also analyzed. The objectives of this study were to understand the geochemical interactions between formation and fracturing fluids and their consequences in the context of tight gas exploitation. The analysis of this dataset allowed for a comprehensive understanding of the coupled downhole geochemical processes, linked in particular to the action of the oxidative breaker. Flowback fluid chemistries were determined to be the result of mixing of formation brine with the hydraulic fracturing fluids as well as coupled geochemical reactions with the reservoir rock such as dissolution of anhydrite and dolomite; pyrite and organic matter oxidation; and calcite, barite, celestite, iron oxides and possibly calcium sulfate scaling. In particular, excess sulfate in the collected samples was found to be mainly derived from anhydrite dissolution, and not from persulfate breaker or pyrite oxidation. The release of heavy metals from the oxidation activity of the breaker was detectable but concentrations of heavy metals in produced fluids remained below the World Health Organization guidelines for drinking water and are therefore of no concern. This is due in part to the co-precipitation of heavy metals with iron oxides and possibly sulfate minerals.
\end{abstract}

Keywords: Tight gas, hydraulic fracturing, flowback geochemistry, persulfate breaker, heavy metals, stable isotopes

\section{Introduction}

Oil and gas production from unconventional hydrocarbon resources is now more important than ever in the global geopolitical and energy landscape. In 2018, the United States produced a total of 30 Tcf (trillion cubic feet) of natural gas with two-thirds of it coming from tight unconventional plays ( 20 Tcf) [1] and the production of natural gas from unconventional plays is expected to reach $90 \%$ of the total production

${ }^{*}$ Corresponding Author

Email address: florian.osselin@cnrs-orleans.fr (F. Osselin) 
by 2050. In Canada, 34\% of the total production of natural gas originated from the unconventional Montney formation, with almost 2 Tcf produced in 2017 [2]. Other large Canadian tight gas plays such as the Duvernay formation or the Horn River basin in northwestern Alberta and northeastern British Columbia produced another 0.2 Tcf in 2018 [2]. The development and rapid expansion of these low permeability hydrocarbon resources is closely linked to the development of horizontal drilling and multistage hydraulic fracturing over the past 20 years. Hydraulic fracturing techniques involve injecting a fluid (usually water based) at very high pressure in order to fracture the reservoir and open paths for the hydrocarbons to flow to the casing of the horizontal portion of the well. However, there are concerns about increasing freshwater usage especially in zones where the water supply is already under stress $[3,4,5]$. After the hydraulic fracturing operations, the well usually produces variable quantities of saline water along with the produced gas [6]. This water is characterized by high TDS contents (Total Dissolved Solids) $[7,8,9]$ and is considered to be the result of mixing of low salinity injected fracturing fluids with high salinity formation brine $[10,11]$. Additionally, the flowback fluids are often characterized by a strong signature of water rock interactions, principally through the action of the hydraulic fracturing fluids and their additives $[12,13,14]$ on the host rock. Reactions highlighted in the literature include pyrite oxidation by either dissolved oxygen $[15,16,17]$ or the oxidative action of the commonly used persulfate breakers; carbonate dissolution [18]; and the precipitation of different sulfate-bearing minerals such as barite, gypsum or anhydrite [19]. Other interactions such as cation exchange with clay minerals [20], ion diffusion [21] and osmosis may also contribute to changes in flowback and produced water geochemistry. The understanding of the causes of changes in flowback and produced water compositions are of key importance in the design of more optimized and more environmental friendly hydraulic fracturing fluid recipes, while improving the potential of reuse and recycling of such waters, helping to reduce the stress on freshwater resources.

In this study, we present the analysis of a dataset based on 24 flowback water samples taken from one well from a tight gas play in Alberta, Canada during the first week after hydraulic fracturing, and one produced water sample taken from the same well after 14.5 months. These samples were analyzed for concentrations of major ions and traces elements, as well as various stable isotopic compositions. The results were then compared to those of water samples from an additional 16 producing wells sampled 112 days to 3.7 years after commencement of production to determine if similar geochemical processes are occurring in other reservoir portions across the field. These 16 produced water samples were obtained from wells representing a wide spatial area and different stratigraphic intervals within the same target formation to demonstrate that the identified processes were not constrained to one location or interval in the investigated tight unconventional natural gas play.

A portion of this dataset has been previously described in [22] and the mixing behavior between formation water and hydraulic fracturing fluids was demonstrated through the study of conservative species such as $\mathrm{Cl}$ and oxygen and hydrogen isotopes of water. The objective of this second article is to build upon the conclusions of the previous study and to develop a semi-quantitative model of the complex downhole geochemical interactions between formation water, injected fracturing fluids, and reservoir rocks. Chemical and isotopic parameters, including the isotopic composition of sulfate, were used to elucidate the sources of flowback and produced water constituents and to understand the interplay between hydraulic fracturing fluids, formation brine and reservoir minerals such as dolomite, pyrite and anhydrite.

\section{Study site, well completions and sampling}

Tight gas wells drilled in the Montney Formation in the provinces of Alberta and British Columbia (Figure 1) remain among the top producers in Canada, with 570 wells drilled in 2018. The Montney Formation is a dark dolomitic siltstone interbedded with shale of lower Triassic age. This siltstone is composed primarily of quartz, illite, dolomite and K-feldspar with a high pyrite contents (varying from $<1.0 \%$ up to $4.0 \%)[23,24]$. Petrophysical properties associated with this formation are: $3 \%$ porosity, permeability of 10 $\mu \mathrm{D}$ [25] and water saturation of $31 \%$ [26, 27]. The Montney Formation is overlain by the Doig Formation of Middle Triassic age, characterized by a phosphatic black shale unit; and is lying unconformably above the Permian Belloy Formation [28]. The diagenetic history of the Montney Formation involves strong dolomitization of the calcite and reduction of the initial dissolved sulfate content to sulfide that was subsequently 

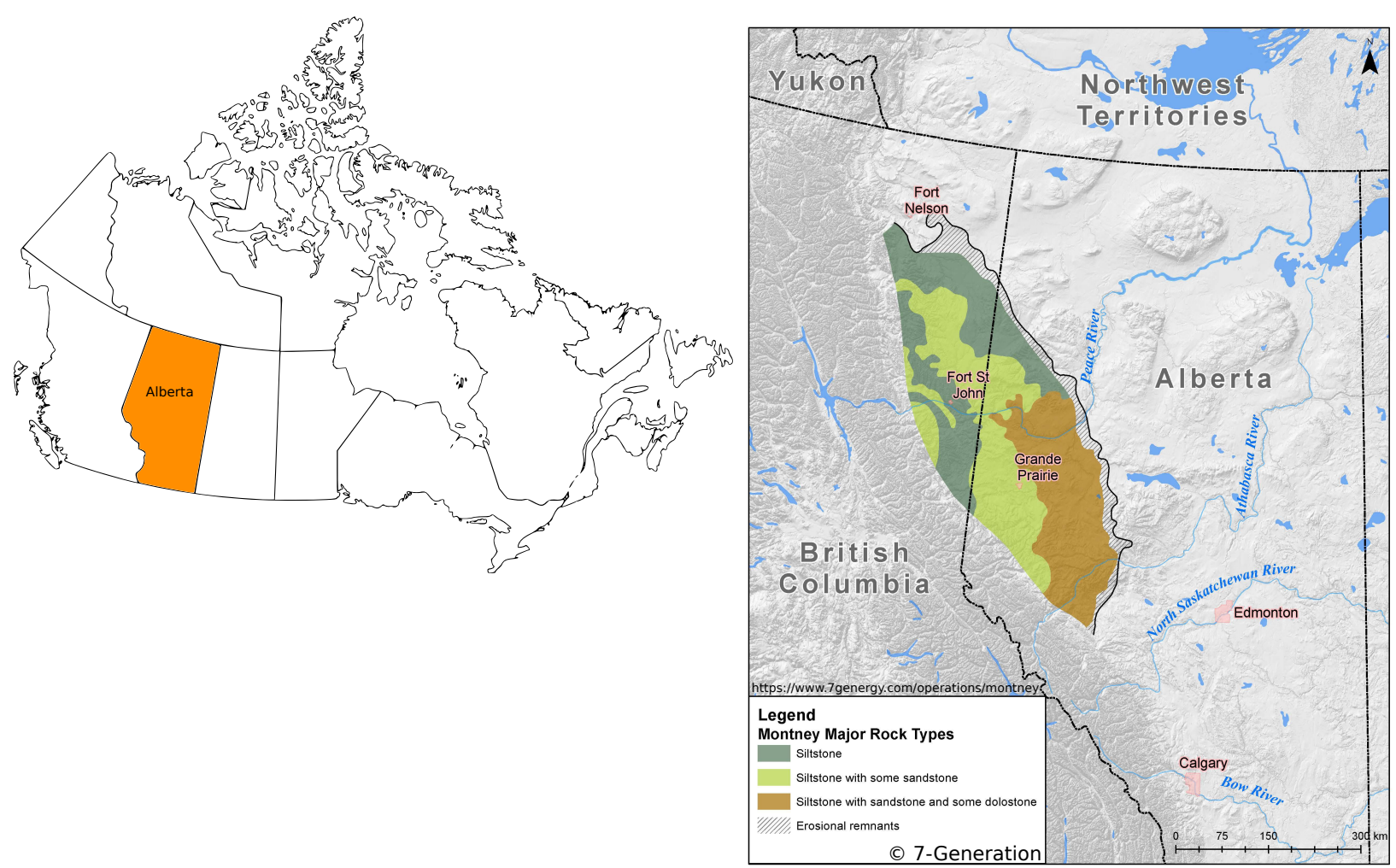

Figure 1: Location of the Montney formation straddling Alberta and British Columbia. 
converted to pyrite [29]. The Montney Formation also contains minor amounts (usually $<1.0 \%$, sometimes up to several \%) of early and late diagenetic anhydrite [30].

Previously, formation waters from tight gas reservoirs were not considered in the hydrogeological and geochemical studies of the area. However, in the Western Canadian Sedimentary Basin, formation waters are generally believed to originate from the evaporation of seawater past the point of halite saturation that were later diluted by various extents of less concentrated saline fluids, or even meteoric waters [31, 32]. In particular, it is believed that some high TDS formation waters in Alberta are sourced from residual brines from the evaporite rich Charlie Lake Formation [28].

\subsection{High-frequency sampling from a hydraulically fractured well}

A well targeting the Middle Montney Formation was drilled to a true vertical depth of $3300 \mathrm{~m}$ before deviating to the $3000 \mathrm{~m}$ long horizontal section. The horizontal wellbore was completed using 28 fracture stages separated by approximately $106 \mathrm{~m}$. Fracturing was conducted with a mixture of nitrogen $(135,000$ $\mathrm{m}^{3}$ under standard conditions per stage) and water $\left(280 \mathrm{~m}^{3}\right.$ per stage $)$ at a pressure of around 9000 psi. Samples were collected once every $20 \mathrm{~m}^{3}$ until $100 \mathrm{~m}^{3}$ of flowback and once every $100 \mathrm{~m}^{3} \mathrm{until}_{1600 \mathrm{~m}^{3} \mathrm{of}}$ flowback. The last two samples were obtained at $2000 \mathrm{~m}^{3}$ of flowback (after 7 days) and 14.5 months after the hydraulic fracturing, corresponding to a total of $18,000 \mathrm{~m}^{3}$ of produced water.

Following the literature consensus, the term flowback water will be used in the following to characterize the 24 samples collected in the first week after commencement of production while produced water will be used to characterize the other samples collected months or years after hydraulic fracturing occurred.

\subsection{Produced waters from multiple wells across the field}

In addition, 16 samples of produced water were collected from 16 horizontal wells on four pads throughout the same tight unconventional natural gas play in northwestern Alberta. The total vertical depths of the wells ranged from 2874 to $3212 \mathrm{~m}$ (mean $3030 \mathrm{~m}$ ) and the horizontal sections were between $1508 \mathrm{~m}$ and $3184 \mathrm{~m}$ long (mean $2438 \mathrm{~m}$ ). The majority of the wells were fractured using slickwater, whereas five wells were hydraulically fractured using a nitrogen foam approach. The number of fracture stages ranged from 19 to 60 , with an average of 30 stages. The samples were collected from the separator between 3.7 and 45.3 months after the "on production" date. Producing zones represented in these produced water samples include the entire Montney Formation succession (i.e. Upper, Middle and Lower Montney).

\subsection{Pyrite, anhydrite and persulfate samples}

In addition to the flowback and produced water samples, a total of 12 core plugs were collected from a $222 \mathrm{~m}$ core extending from the base of the Doig Formation down to the Lower Montney Formation. Three samples from the Upper Montney, four from the Middle Montney and five from the Lower Montney Formation were collected for mineralogical, chemical and isotopic analyses. All plugs were preserved with three layers of protective wrapping.

Four persulfate breaker samples representing chemicals typically used in hydraulic fracturing operations were obtained from three service companies for geochemical and isotopic analyses. The samples represent potassium and sodium persulfate and were encapsulated with a water-resistant coating.

Finally, some additional core plugs were obtained from several wells within the area that penetrated the Montney Formation and were used for determining the isotope composition of anhydrite.

\section{Analytical Methods}

\subsection{Flowback and produced water samples}

Flowback water and produced water samples were collected on site while minimizing exposure to oxygen and stored in $1 \mathrm{~L}$ plastic bottles. Bottles were then shipped within a few days to the University of Calgary (Calgary, Alberta, Canada) for chemical and isotopic analyses. 


\subsubsection{Major ion analysis}

Upon arrival at the laboratory, flowback and produced water samples were filtered through a $0.45 \mu \mathrm{m}$ nitrocellulose filter before acidifying cation samples to $\mathrm{pH}<2$, while samples for anion analysis were not acidified. Cation concentrations were determined by ICP-OES (Inductively Coupled Plasma - Optical Emission Spectrophotometer) on a Varian 725-ES, while anion concentrations were measured by ion chromatography (Dionex ICS 2000). Electric conductivity and pH were obtained with Orion Star instruments and bicarbonate alkalinity was measured using an Orion 960 Titrator. The Total Dissolved Solid value was calculated by adding all the measured concentrations of major ions. Consistency of the results was confirmed by checking that the ionic balance is $<5 \%$ for each sample. Analytical precision and accuracy for anion and cation analysis is typically $\pm 5 \%$.

\subsubsection{Trace elements}

Trace element concentrations on the flowback water samples were measured at the French Geological Survey (BRGM, France) on a Thermo Scientific XSERIES 2 ICP-MS (Inductively Coupled Plasma - Mass Spectrometry). Analytical quality was controlled by internal standard addition (In and Re) and regular international geo-standard (i.e. SLRS4) measurements. The precision for trace element concentrations is generally better than $5 \%$.

\subsubsection{Stable isotope compositions of dissolved sulfate ( $\delta^{34} S$ and $\left.\delta^{18} O\right)$}

Sulfur and oxygen isotope ratios of dissolved sulfate were measured on all flowback and produced water samples by first converting dissolved sulfate to pure $\mathrm{BaSO}_{4}$, which was subsequently thermally decomposed in an elemental analyzer yielding $\mathrm{SO}_{2}$ and a pyrolysis reactor yielding $\mathrm{CO}$ for isotope ratio mass sperctrometry. Results of the isotope ratio analyses are reported in the delta notation $(\delta)$ with V-SMOW (Standard Mean Ocean Water) as the reference for oxygen isotopes of sulfate, and V-CDT (Vienna Canyon Diablo Troilite) for sulfur isotope ratios. Analytical uncertainties are $\pm 0.3 \%$ and $\pm 0.5 \%$ for $\delta^{34} S$ and $\delta^{18} \mathrm{O}$ values of sulfate, respectively.

\subsection{Sulfur in core samples}

Based on XRD, sulfur in the core samples occurred predominantly as pyrite $\left(\mathrm{FeS}_{2}\right)$. Total sulfur contents ranges from $0.45 \%$ in the Upper Montney to $1.59 \%$ in the Lower Montney, with an average of $0.9 \%$ across the entire Montney Formation. The $\delta^{34} S$ values of total sulfur, representing predominantly pyrite, were determined on powdered core samples that were thermally decomposed in an elemental analyzer followed by isotope ratio mass spectrometry in continuous flow mode. For anhydrite sulfur isotope ratio, small powdered aliquots of the core samples were reacted with $\mathrm{HCl}$ and then filtered to separate the sulfate (dissolved anhydrite) from the sulfide (pyrite). Barium chloride $\left(\mathrm{BaCl}_{2}\right)$ was then added to the solution and the sample was heated for approximately 30 minutes to allow for the barium sulfate $\left(\mathrm{BaSO}_{4}\right)$ to precipitate. The $\mathrm{BaSO}_{4}$ samples were then placed into silver cups and the $\delta^{34} S$ value was measured using Continuous Flow-Isotope Mass Spectrometry. Results are expressed relative to V-CDT with a measurement uncertainty of $\pm 0.5 \%$.

\section{3. $S$ and $O$ isotope ratios of persulfate breakers}

The isotopic composition of sulfate from the decomposition of the four persulfate breaker samples was also determined by thermal decomposition in an elemental analyzer yielding $\mathrm{SO}_{2}$ and a pyrolysis reactor yielding $\mathrm{CO}$ for isotope ratio mass spectrometry with measurement uncertainties of $\pm 0.3 \%$ and $\pm 0.5 \%$ o for $\delta^{34} S$ and $\delta^{18} \mathrm{O}$ values of sulfate, respectively.

\section{Results}

\subsection{Methodology}

Similar to most previous flowback studies (e.g. $[7,8,10])$, the TDS of the flowback samples in this study increased quickly as the result of the mixing of low salinity hydraulic fracturing fluids with high salinity 
formation water [22]. In order to separate the contributions from water-rock interactions, from the simple mixing between formation water and fracturing fluids, the different species of interest are plotted against $\mathrm{Cl}$ concentrations. In the absence of halite dissolution, chloride can be considered as conservative [13, 33]. As such, the $\mathrm{Cl}$ concentrations are representative of the relative proportions of fracturing fluids and formation water in the samples as described in [22]: $\frac{V_{i n j}}{V_{i n j}+V_{f o r m}}=\frac{[\mathrm{Cl}]_{s p l}-[\mathrm{Cl}]_{\infty}}{[\mathrm{Cl}]_{0}-[\mathrm{Cl}]_{\infty}}$ with $V_{i n j}$ the volume of injected water in the sample and $V_{\text {form }}$ the volume of formation water in the sample, while $V_{\text {form }}+V_{\text {inj }}=V_{\text {spl }} ;[\mathrm{Cl}]_{s p l}$ is the chloride concentration in the sample while $[\mathrm{Cl}]_{0}$ and $[\mathrm{Cl}]_{\infty}$ are respectively the concentrations of chloride in the hydraulic fracturing fluid and in the formation water. Another option for a conservative tracer would be bromide but the dataset did not include this element. The conservative behavior of $\mathrm{Cl}$ was also confirmed in [22] using stable isotopes of water.

The advantage of plotting the different water constituents against $\mathrm{Cl}$ is that it allows the identification of conservative and non-conservative species. Indeed, if a species is conservative, it will correlate exactly with $\mathrm{Cl}$ and the data points should plot on a line connecting the hydraulic fracturing fluid composition to the formation water composition (red lines on the different figures). Any species plotting above or below the line reveals a non-conservative behavior with more or less of the species than conservative mixing would predict and thus, a source or sink of this species is required. This behavior is likely the result of water-rock interactions.

A complete results table can be found in Supplementary Materials.

\subsection{Chemical and isotopic composition of flowback samples}

The mixing of fracturing fluids with formation water as well as water-rock interactions caused the TDS contents of the flowback samples to increase rapidly and steadily from $396 \mathrm{mg} / \mathrm{l}$ in the fracturing fluid to $96,000 \mathrm{mg} / \mathrm{l}$ after 7 days of flowback, and up to $204,000 \mathrm{mg} / \mathrm{l}$ for the produced water sample obtained after 14.5 months (Figure 2 and table SI-1).

Figures 3a-d and table SI-1 show the evolution of $\mathrm{Ca}(\mathrm{a}), \mathrm{Mg}(\mathrm{b}), \mathrm{Ba}(\mathrm{c})$ and $\mathrm{Sr}(\mathrm{d})$ concentrations in flowback and produced water samples versus $\mathrm{Cl}$ concentrations. In Figures $3 \mathrm{a}$ and $3 \mathrm{~b}, \mathrm{Ca}$ and $\mathrm{Mg}$ concentrations increased from 71 and $18 \mathrm{mg} / 1$ in the fracturing fluids to 4,200 and $800 \mathrm{mg} / \mathrm{l}$ after 7 days of flowback, and further to 7,900 and $1,200 \mathrm{mg} / 1$ respectively after 14.5 months of production. Figures $3 a$ and $3 \mathrm{~b}$ reveal that the $\mathrm{Ca}$ and $\mathrm{Mg}$ concentrations in flowback waters obtained between days 2 and 7 plot above the conservative mixing line between fracturing fluids and formation water, hence indicating an additional source of $\mathrm{Ca}$ and $\mathrm{Mg}$.

$\mathrm{Ba}$ and $\mathrm{Sr}$ concentrations increased from $0.16 \mathrm{mg} / \mathrm{l}$ and $0.52 \mathrm{mg} / \mathrm{l}$ in the fracturing fluids to 2.2 and 170 $\mathrm{mg} / \mathrm{l}$ after 7 days, and further to 8.3 and $640 \mathrm{mg} / \mathrm{l}$, respectively, after 14.5 months of production. Figures $3 \mathrm{c}$ and $3 \mathrm{~d}$ reveal that the $\mathrm{Ba}$ and $\mathrm{Sr}$ concentrations of flowback waters obtained after the beginning of day 2 for Ba and day 1 for Sr plot below the conservative mixing line between fracturing fluids and formation water, indicating some removal of Ba and $\mathrm{Sr}$ from the flowback fluids.

Figure 4 and table SI- 1 show the evolution of sulfate concentrations in flowback fluids versus chloride concentrations in all collected samples. Sulfate concentrations increased from $61 \mathrm{mg} / \mathrm{l}$ in the hydraulic fracturing fluid to $780 \mathrm{mg} / \mathrm{l}$ in the flowback sample taken only a couple of hours later and then remained rather constant (varying only between 690 and $880 \mathrm{mg} / \mathrm{l}$ ) in samples obtained between the end of day 1 and day 7. After 14.5 months, the sulfate concentration had decreased to $210 \mathrm{mg} / \mathrm{l}$. The cross-plot of sulfate versus chloride concentrations indicates a highly non-conservative behavior of sulfate.

To elucidate additional sources of sulfate in flowback waters, $\delta^{34} S$ values of sulfate in the flowback and produced water samples were determined and plotted versus sulfate and chloride concentrations in Figures $5 \mathrm{a}$ and $5 \mathrm{~b}$, respectively. $\delta^{34} S$ values of sulfate increased from $+6.4 \%$ in the hydraulic fracturing fluid exponentially to $\approx+23 \%$ ofter 7 days and further to $+26.4 \%$ after 14.5 months. A cross-plot of $\delta^{34} S$ values versus $\delta^{18} \mathrm{O}$ values of sulfate is shown in Figure 5c. Oxygen isotope ratios of sulfate increase similarly from $0 \%$ o to $12.6 \%$ after the first week of flowback. Unfortunately, the last sample obtained after 14.5 months was not analyzed for oxygen isotope ratios of sulfate.

Analysis of the concentrations of traces metals revealed that $\mathrm{As}, \mathrm{Ni}, \mathrm{Pb}, \mathrm{Ti}$, Th and $\mathrm{Zn}$ are characterized by a distinctive pattern (table SI-1): while both the hydraulic fracturing fluid and the last sample obtained 


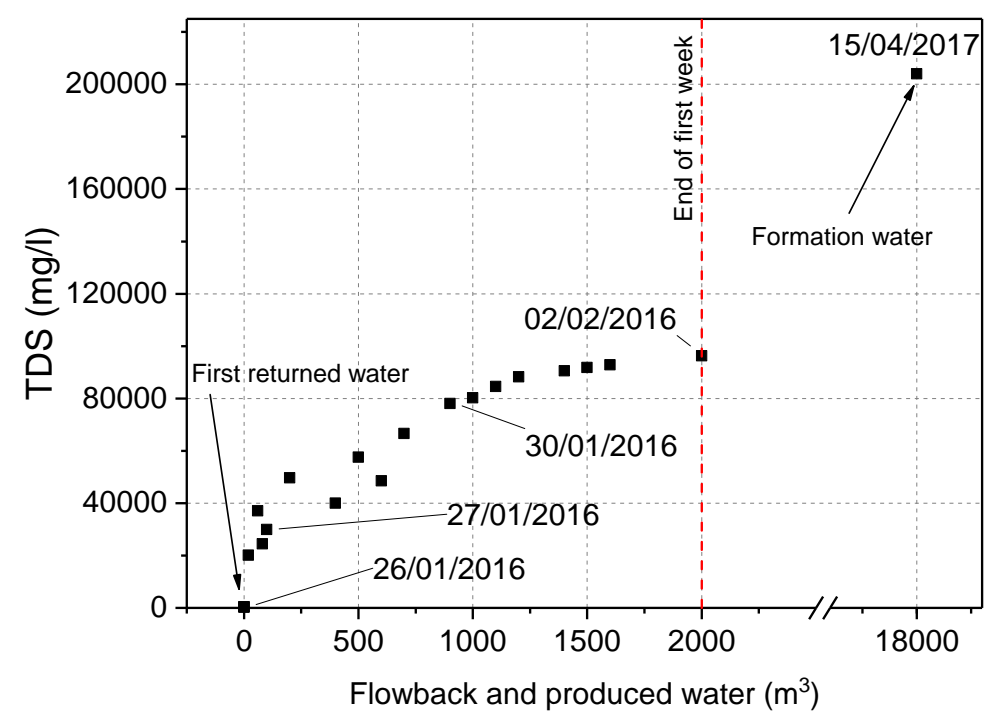

Figure 2: Evolution of TDS in samples versus volume of flowback and produced water.
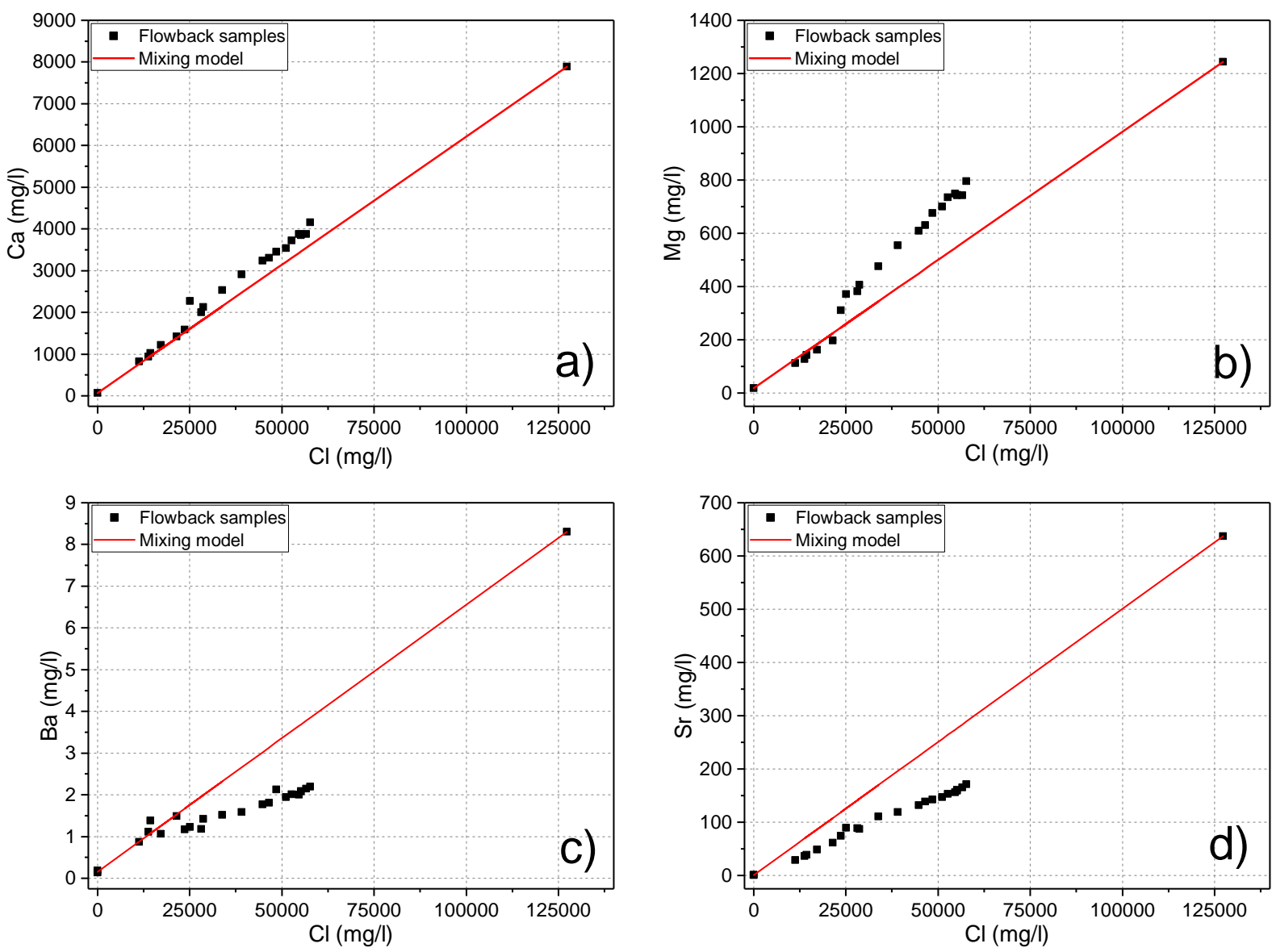

Figure 3: Evolution of calcium (a), magnesium (b), barium (c) and strontium (d) concentrations plotted versus chloride concentrations in flowback and produced water samples and the corresponding conservative mixing lines between fracturing fluids and formation water based on the conservative parameter $\mathrm{Cl}^{-}$. 


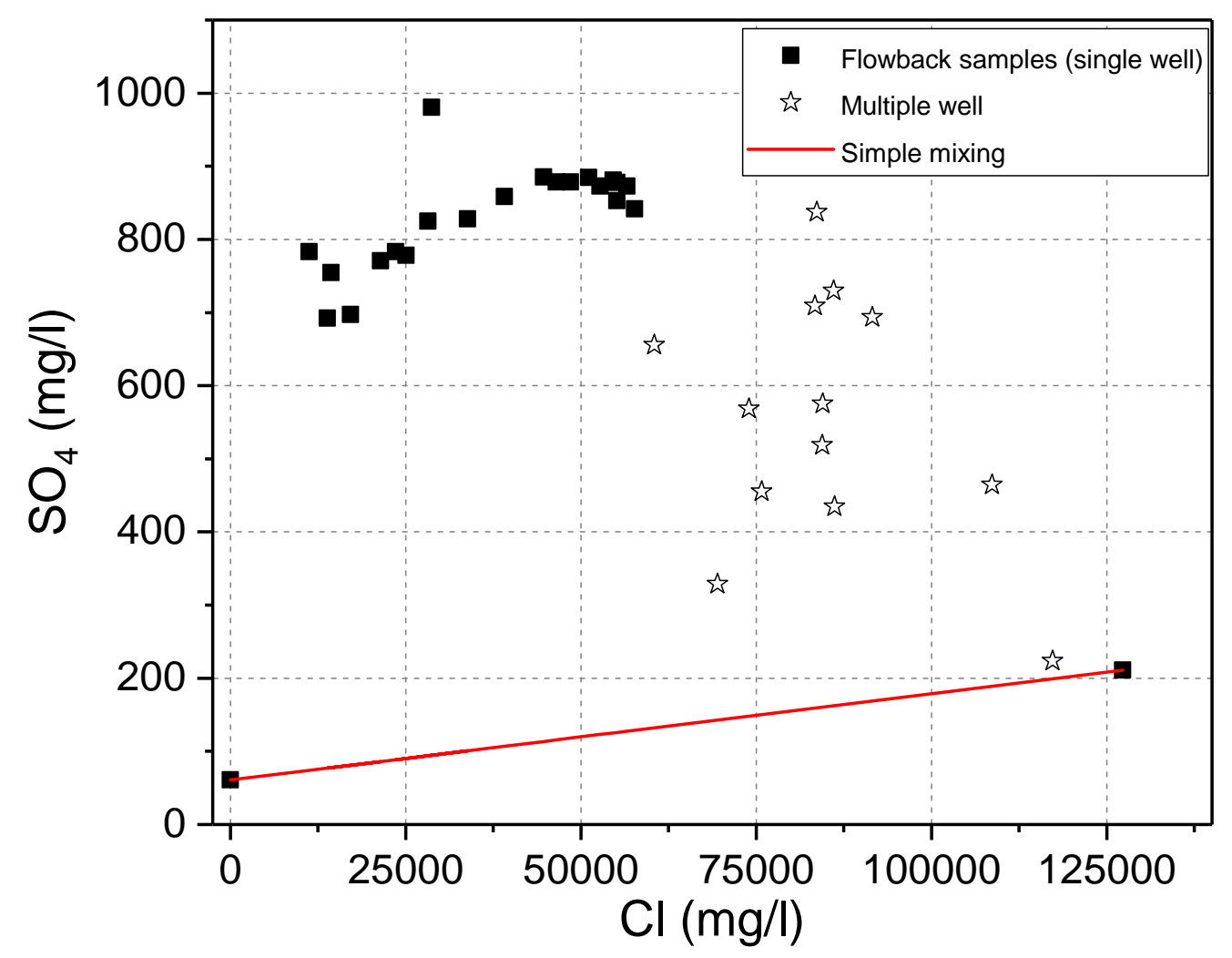

Figure 4: Evolution of sulfate concentration in flowback and produced water versus chloride concentrations. 

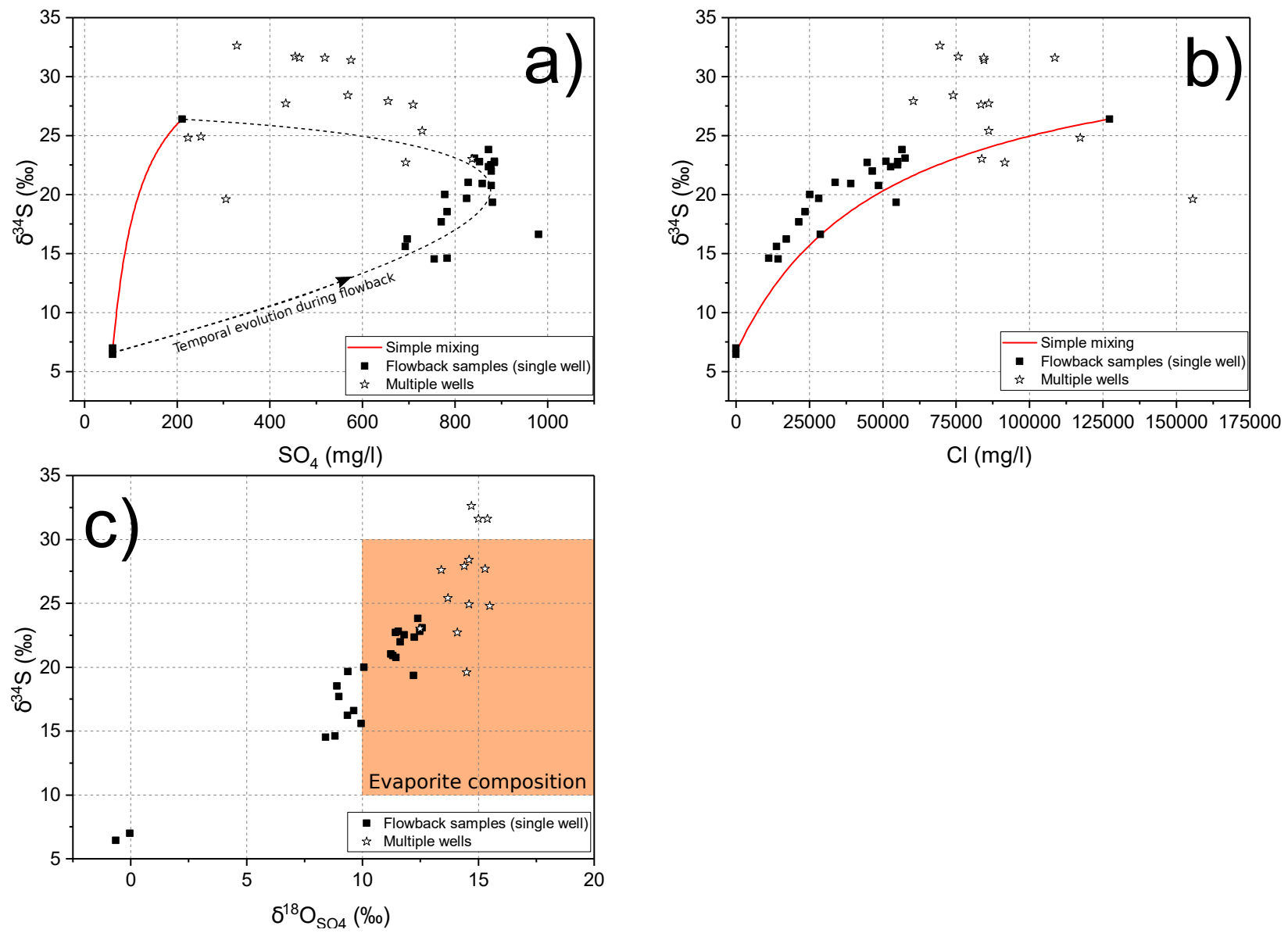

Figure 5: Evolution of $\delta^{34} S$ values of dissolved sulfate plotted versus dissolved sulfate (a) and chloride (b) concentrations, and crossplot of $\delta^{34} S$ and $\delta^{18} \mathrm{O}$ values of dissolved sulfate (c). 

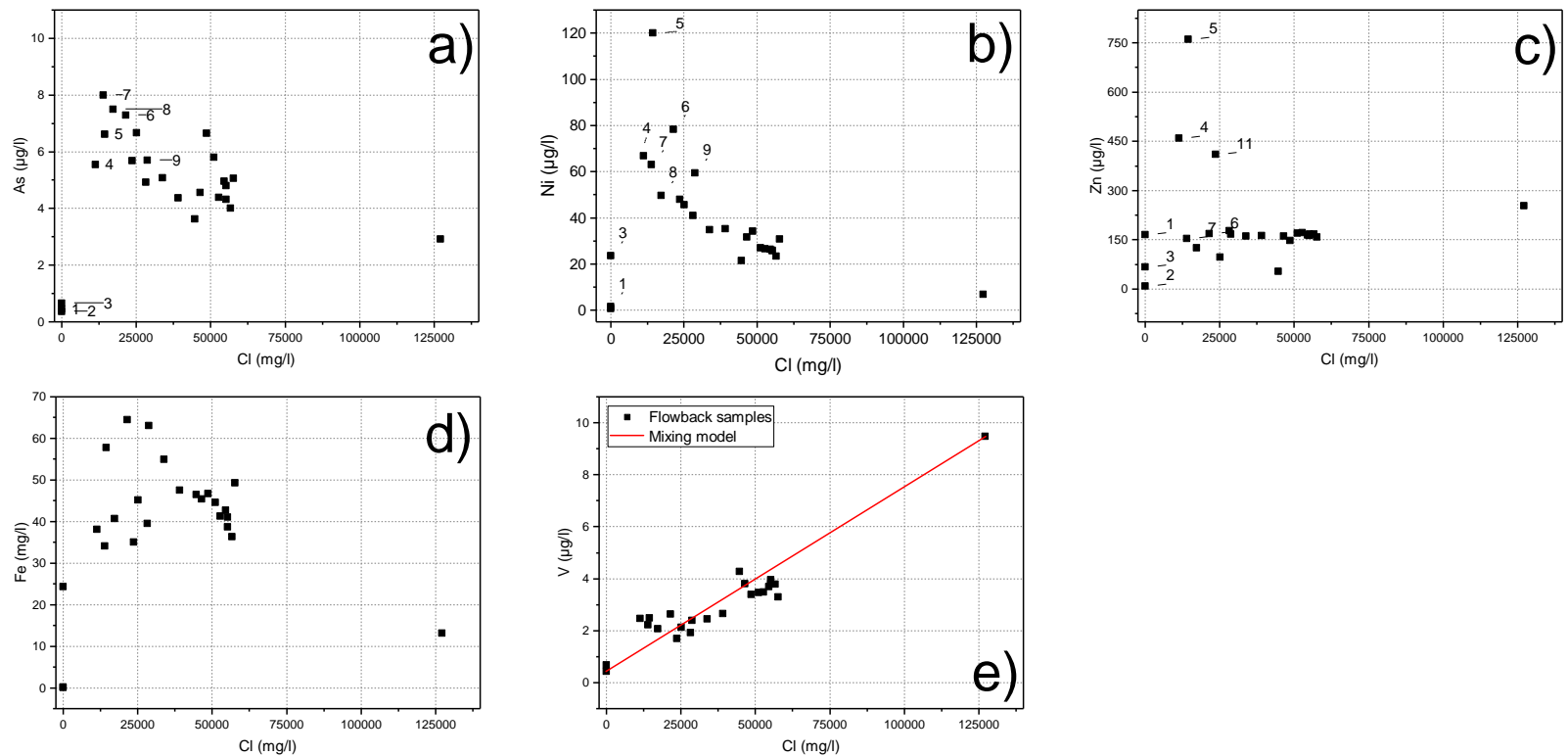

Figure 6: Evolution of arsenic (a), nickel (b), zinc (c), iron (d) and vanadium (e) concentrations in flowback samples plotted versus chloride concentrations - the labels correspond to the sequence of samples

after 14.5 months of production have low concentrations, shortly after the beginning of the flowback, the concentrations of these elements spiked as shown in Figures 6a-c for As, Ni and $\mathrm{Zn}$ respectively. The concentrations follow then a quick decrease toward the composition of the formation water. For $\mathrm{Pb}$, the peak concentration occurred slightly later than the other trace elements at a $\mathrm{Cl}$ concentration of $14000 \mathrm{mg} / \mathrm{l}$ (i.e. at 4 hours of flowback), while most of the trace elements displayed a peak concentration as early as $\mathrm{Cl}$ concentration of $11000 \mathrm{mg} / 1$ (i.e. 1.5 hours after the beginning of flowback). The decrease in these trace metal concentrations after the peak is different for each element with the sharpest decrease for $\mathrm{Zn}$, and the slowest decrease for As. Fe concentrations shown in Figure 6d display a similar pattern to the other trace elements with a sharp increase in the early flowback from $0.22 \mathrm{mg} / \mathrm{l}$ to $64.5 \mathrm{mg} / \mathrm{l}$ after 9 hours and a very slow decrease to $36 \mathrm{mg} / \mathrm{l}$ after a week. The sample collected after $14.5 \mathrm{months}$ had an Fe concentration which had further decreased to $13 \mathrm{mg} / \mathrm{l}$. Finally, Figure 6e presents the evolution of the concentration of vanadium relative to the concentrations of $\mathrm{Cl}$ in flowback and produced water samples. Contrary to the other trace metals $\mathrm{V}$ (and Be) exhibit a steady increase in respective concentrations. The concentration of Be rose from $0.006 \mu \mathrm{g} / 1$ in the fracturing fluid to approximately $0.07 \mu \mathrm{g} / 1$ in the sample after one week of flowback and after 14.5 months the concentration had doubled to $0.14 \mu \mathrm{g} / \mathrm{l}$. The concentration of $\mathrm{V}$ increased from $0.43 \mu \mathrm{g} / 1$ in the hydraulic fracturing water to about $4 \mu \mathrm{g} / 1$ after one week of flowback and $9.5 \mu \mathrm{g} / 1$ after 14.5 months.

\subsection{Chemical and isotopic compositions of produced water samples from multiple wells}

The TDS concentrations of the produced waters from the 16 wells sampled in the vicinity of the above described well ranged from 102,000 mg/l in the well sampled after 118 days to $252,000 \mathrm{mg} / \mathrm{l}$ in the well sampled after 1202 days after commencement of production (mean 151,000 mg/l). TDS concentrations in produced waters increased with increasing number of days after production commenced. Sulfate concentrations in produced waters ranged from $220 \mathrm{mg} / \mathrm{l}$ in the well sampled after 1202 days to $840 \mathrm{mg} / \mathrm{l}$ in the well that was sampled after 301 days (mean $530 \mathrm{mg} / \mathrm{l}$ ) (Figure 4). In contrast to TDS, sulfate concentrations in produced waters were highest $(>600 \mathrm{mg} / \mathrm{l}$ ) in wells that were sampled within 200 to 600 days after commencement of production and which target the Upper Montney Formation. The lowest sulfate concentrations $(<300 \mathrm{mg} / \mathrm{l})$ were associated with produced waters from wells that were sampled more than 800 days after commencement of production, from the same pad. Figure 4 reveals that sulfate concentrations 
of produced waters from the 16 wells display a trend of decreasing sulfate with increasing chloride concentrations and plot between the flowback samples (first week) from the single well and the produced water sample taken 14.5 months later.

Sulfur isotope ratios of the dissolved sulfate in produced waters ranged from $19.6 \%$ o to $36.2 \%$ while oxygen isotope ratios of sulfate in produced waters ranged from $12.5 \%$ o to $15.4 \%$ o. Figures $5 \mathrm{a}$ and $\mathrm{b}$ reveals that data for produced waters from the 16 wells plot between the first samples from the single well and the last sample taken after 14.5 months, similarly to Figure 4. On Figure $5 c$, the data for sulfate from the 16 wells extent the trend of sulfate isotope compositions from the flowback fluids of the single well.

\subsection{Potential sources of additional sulfate and their isotopic fingerprints}

The highly non-conservative behavior of sulfate concentrations in flowback fluids shown in Figure 4 suggests the existence of additional sulfate sources (on top of the sulfate derived from mixing with formation water) that appear to contribute in variable quantities to flowback fluids and produced waters as a function of time. These sources of additional sulfate include a) sulfate sourced from the decomposition of the ammonium persulfate breaker $\left(\left(\mathrm{NH}_{4}{ }^{+}\right)_{2} \cdot \mathrm{S}_{2} \mathrm{O}_{8}{ }^{2-}\right)$, b) sulfate derived from pyrite $\left(\mathrm{FeS}_{2}\right)$ oxidation, and c) sulfate derived from anhydrite dissolution $\left(\mathrm{CaSO}_{4}\right)$. Ammonium persulfate is a strong oxidant $\left(\mathrm{E}^{\circ}=2.6\right.$ $\mathrm{V}$ [34]) used for breaking the guar gum in order to reduce the viscosity of the fluid upon flowback [35], reacting as follows:

$$
\begin{aligned}
\mathrm{S}_{2} \mathrm{O}_{8}{ }^{2-} & =2 \mathrm{SO}_{4}{ }^{-\cdot} \\
\mathrm{SO}_{4}{ }^{-\cdot}+\mathrm{H}_{2} \mathrm{O} & =\mathrm{SO}_{4}{ }^{2-}+\mathrm{H}^{+}+\mathrm{HO}^{-\cdot} \\
\text { Guar }+\mathrm{HO}^{-\cdot} & =\text { Guar }{ }^{\cdot}+\mathrm{H}_{2} \mathrm{O}
\end{aligned}
$$

The four persulfate breaker samples were found to have $\delta^{34} S$ values of $+5.5,+3.7,-1.5$ and $-5.0 \%$ o yielding a mean $\delta^{34} S$ value of $0.7 \pm 4.8 \%$. This average $\delta^{34} S$ value is considered representative for persulfate breakers used in the industry.

$\delta^{34} S$ values of total sulfur in the core samples, that is predominantly represented by pyrite, varied considerably from -20 to $+15 \%$ o. Using concentration and $\delta^{34} S$ values an amount-weighted average $\delta^{34} S$ value for pyrite of $-1.1 \%$ for the entire Montney section, and an amount-weighted average $\delta^{34} S$ value of $1.6 \%$ for the pyrite in Middle Montney Formation was determined. As a consequence, a $\delta^{34} S$ value of $0 \%$ o for pyrite, and for sulfate derived from pyrite oxidation was used for this study.

And finally, a $\delta^{34} S$ value of anhydrite was measured for small amounts of sulfate leached from the Montney Formation core samples. Results ranged from +16 to $+22 \%$ while [36] reported $\delta^{34} S$ values as high as $+28.8 \%$ for anhydrite extracted from the Montney Formation. In addition, anhydrite at the interface of the Upper Montney and the overlying Doig Formation was found to have $\delta^{34} S$ values ranging from +24 to $+26 \%$ o [29]. Therefore, sulfate derived from anhydrite dissolution is expected to have $\delta^{34} S$ values as high as $+25 \pm 3 \%$, whereas sulfate from pyrite oxidation or persulfate breakers would be characterized by $\delta^{34} S$ near $0 \%$, with the latter two sources being indistinguishable based on sulfur isotope fingerprints.

Another phenomenon which could impact the sulfur isotope systematics is bacterial sulfate reduction (BSR), which reduces sulfate to sulfide and is known to be accompanied by strong isotope fractionation $(\sim 30 \%$ o $-[37,38])$ for both sulfur and oxygen affecting the remaining sulfate. Figure $5 c$, shows that the oxygen isotopes of dissolved sulfate in produced water are around $+15 \%$. $\delta^{18} \mathrm{O}$ values of dissolved sulfate in the flowback samples plot between the value of the hydraulic fracturing fluid and that of sulfate in the produced waters. Considering that typical $\delta^{18} \mathrm{O}$ values of sulfate in natural evaporites plot between +10 and $+20 \%$ and +10 and $+30 \%$ o for $\delta^{34} S[39,40]$, it is unlikely that extensive bacterial sulfate reduction is occurring during the flowback as such a process would result in oxygen and sulfur isotope ratio of sulfate much higher than the ones recorded. The high salinity of the flowback samples [41] may explain the limited extent of BSR in the flowback and produced fluids from the investigated well. 


\section{Discussion}

\subsection{Elucidating sources of sulfate}

Chemical and isotopic data were used in a semi-quantitative model to reveal the sources of sulfate and its dependence on flowback volume and time. The model considers that each sample contains sulfate from both the hydraulic fracturing fluid and the formation water, as well as sulfate from the breaker decomposition and additional sulfate potentially being derived from the water-rock interactions as expressed in equation (4).

$$
\left[\mathrm{SO}_{4}\right]_{s p l}=\left[\mathrm{SO}_{4}\right]_{0} f+\left[\mathrm{SO}_{4}\right]_{\infty}(1-f)+\left[\mathrm{SO}_{4}\right]_{\chi}
$$

where $\left[\mathrm{SO}_{4}\right]_{s p l}$ is the sulfate concentration in the sample, $\left[\mathrm{SO}_{4}\right]_{0}$ the sulfate concentration in the injected water, $\left[\mathrm{SO}_{4}\right]_{\infty}$ the sulfate concentration in the formation water and $\left[\mathrm{SO}_{4}\right]_{\chi}$ the concentration of sulfate from additional sources (i.e. water-rock interactions and persulfate decomposition). The mixing ratio $f$ is defined as $f=\frac{V_{i n j}}{V_{i n j}+V_{f o r m}}=\frac{[\mathrm{Cl}]_{s p l}-[\mathrm{Cl}]_{\infty}}{[\mathrm{Cl}]_{0}-[\mathrm{Cl}]_{\infty}}$ with chloride considered as conservative.

Similarly S isotope ratios of sulfate in the sample can be expressed as follow (e.g. [42]):

$$
\delta_{\text {spl }}=\frac{\delta_{0}\left[\mathrm{SO}_{4}\right]_{0} f+\delta_{\infty}\left[\mathrm{SO}_{4}\right]_{\infty}(1-f)+\delta_{\chi}\left[\mathrm{SO}_{4}\right]_{\chi}}{\left[\mathrm{SO}_{4}\right]_{s p l}}
$$

Decomposing the $\mathrm{S}$ isotopic ratio according to the three identified additional sources (anhydrite, pyrite oxidation and persulfate decomposition), equation (5) can be written as:

$$
\delta_{\chi}=\frac{\left[\mathrm{SO}_{4}\right]_{a n} \delta_{a n}+\left[\mathrm{SO}_{4}\right]_{p e r} \delta_{p e r}+\left[\mathrm{SO}_{4}\right]_{p y r} \delta_{p y r}}{\left[\mathrm{SO}_{4}\right]_{\chi}}
$$

with the subscripts an, per and pyr meaning sulfate sourced respectively from anhydrite dissolution, persulfate decomposition and pyrite oxidation. Since $\left[\mathrm{SO}_{4}\right]_{\chi}=\left[\mathrm{SO}_{4}\right]_{a n}+\left[\mathrm{SO}_{4}\right]_{p e r}+\left[\mathrm{SO}_{4}\right]_{p y r}$, equation (6) can be rewritten as follows:

$$
\delta_{\chi}=\delta_{a n}+\frac{\left[\mathrm{SO}_{4}\right]_{p e r}}{\left[\mathrm{SO}_{4}\right]_{\chi}}\left(\delta_{p e r}-\delta_{a n}\right)+\frac{\left[\mathrm{SO}_{4}\right]_{p y r}}{\left[\mathrm{SO}_{4}\right]_{\chi}}\left(\delta_{p y r}-\delta_{a n}\right)
$$

Pyrite oxidation in the hydraulically fractured reservoir can be stimulated by the remaining dissolved oxygen in the hydraulic fracturing water, or from the attack of persulfate. The injected water was submitted to an oxygen removal stage before injection and hence it was assumed that the oxidation of pyrite is predominantly caused by persulfate. The reaction can be summarized by the following equation:

$$
2 \mathrm{FeS}_{2}+15 \mathrm{~S}_{2} \mathrm{O}_{8}{ }^{2-}+16 \mathrm{H}_{2} \mathrm{O}=2 \mathrm{Fe}^{3+}+34 \mathrm{SO}_{4}{ }^{2-}+32 \mathrm{H}^{+}
$$

Equation (8) reveals that 15 moles of persulfate are required to oxidize 2 moles of pyrite, producing 34 moles of sulfate, 30 of which come from the persulfate decomposition and 4 of which come from the pyrite. As a result, we can write that $\left[\mathrm{SO}_{4}\right]_{p y r}=\frac{4}{15} \alpha[\mathrm{per}]$ with $\alpha$ representing the proportion of persulfate oxidizing the pyrite and $[\mathrm{per}]$ the quantity of persulfate which reacted in the sample. Since the primary purpose of persulfate is to breakdown the guar gum, it can be assumed that $\alpha$ is small.

The initial quantity of persulfate added to the injected water in this well was $[\text { per }]_{0} \approx 200 \mathrm{mg} / 1(0.2$ $\mathrm{kg} / \mathrm{m}^{3}$ ). One mole of persulfate will, upon reacting with pyrite or guar gum, produce 2 moles of sulfate according to the mechanism of equations (1) and (2). The quantity of sulfate coming from persulfate decomposition in a sample will then be:

$$
\begin{aligned}
& {\left[\mathrm{SO}_{4}\right]_{\text {per }}=f\left[2\left([\text { per }]_{0}-[\text { per }]_{\text {unreacted }}\right)-\left[\mathrm{SO}_{4}\right]_{\text {per }}^{\text {precipitated }}\right]} \\
& {\left[\mathrm{SO}_{4}\right]_{\text {per }}=2 \beta[\text { per }]_{0} \quad \text { with } \quad \beta=f\left(1-\frac{[\text { per }]_{\text {unreacted }}+1 / 2\left[\mathrm{SO}_{4}\right]_{\text {per }}^{\text {precipitated }}}{[\text { per }]_{0}}\right)}
\end{aligned}
$$




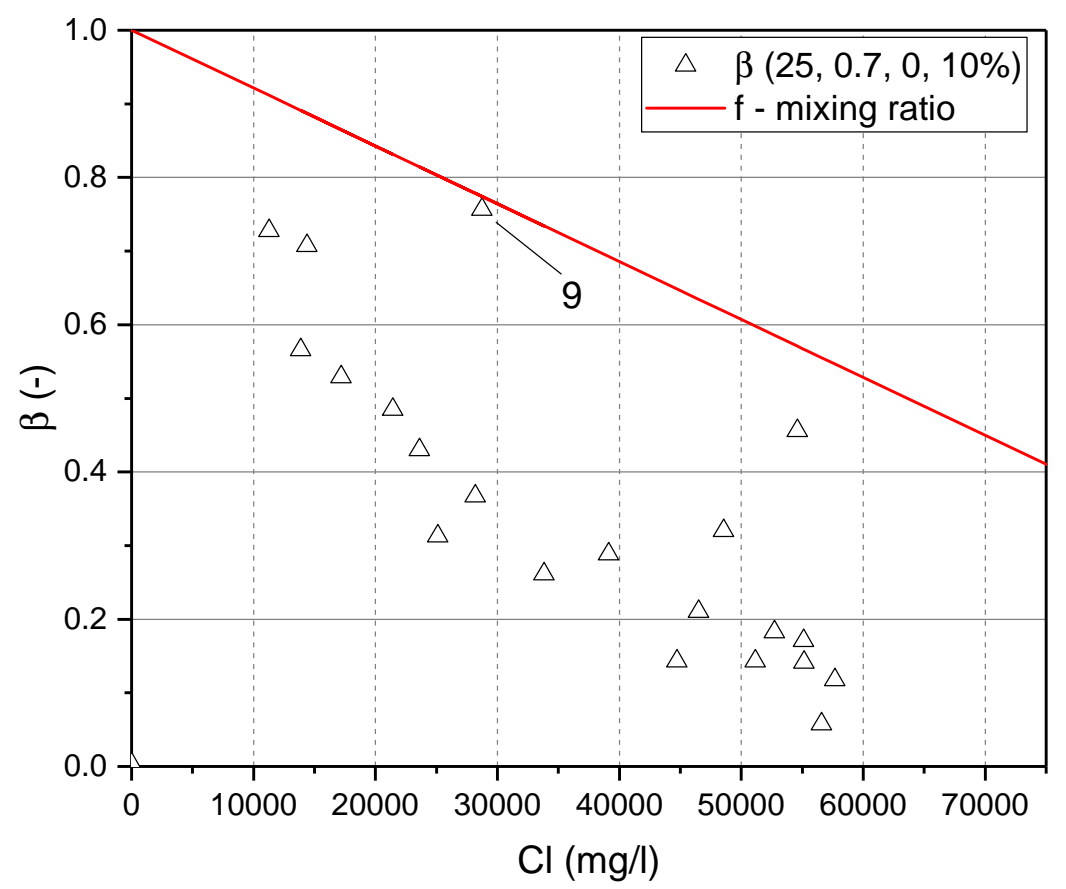

Figure 7: Evolution of parameter $\beta$ with $\mathrm{Cl}$ concentration using $\delta^{34} S$ values from the sulfate sources

where $[\text { per }]_{\text {unreacted }}$ is the quantity of persulfate which did not yet decompose (i.e. still present in persulfate form), and $\left[\mathrm{SO}_{4}\right]_{\text {per }}^{\text {precipitated }}$ is the quantity of sulfate from the decomposition of persulfate which precipitated as sulfate mineral. Parameter $\beta$ characterizes the departure between an ideal case with no precipitation and instantaneous persulfate reaction (i.e. $\beta=f$ ), and reality (i.e. $\beta<f$, $[\text { per }]_{\text {unreacted }}$ and/or $\left.\left[\mathrm{SO}_{4}\right]_{\text {per }}^{\text {precipitated }} \neq 0\right)$.

Combining the previous considerations, we can rewrite (7) as:

$$
\delta_{\chi}=\delta_{a n}+\frac{\beta[p e r]_{0}}{\left[\mathrm{SO}_{4}\right]_{\chi}}\left[2\left(\delta_{p e r}-\delta_{a n}\right)+\frac{4}{15} \alpha\left(\delta_{p y r}-\delta_{a n}\right)\right]
$$

If we combine equations (5) and (11), we can express the $\beta$ parameter:

$$
\beta=\frac{\delta_{\text {spl }}\left[\mathrm{SO}_{4}\right]_{s p l}-\delta_{0}\left[\mathrm{SO}_{4}\right]_{0} f-\delta_{\infty}\left[\mathrm{SO}_{4}\right]_{\infty}(1-f)-\delta_{a n}\left[\mathrm{SO}_{4}\right]_{\chi}}{[\text { per }]_{0}\left[2\left(\delta_{p e r}-\delta_{a n}\right)+\frac{4}{15} \alpha\left(\delta_{p y r}-\delta_{a n}\right)\right]}
$$

Figure 7 displays the evolution of the $\beta$ parameter using the measured $\delta^{34} S$ values from all possible sources: $\delta_{a n}=25 \%$, $\delta_{p y r}=0 \%, \delta_{p e r}=0.7 \%$ and $\alpha=10 \%$. Even if these parameters are not completely constrained (no direct measurement, or in the case of $\alpha$, no literature data or modeling), the system does not allow for much variation: first of all, because of $\alpha$ and the factor $4 / 15$, the contribution from pyrite oxidation toward dissolved sulfate in flowback is negligible and thus its sulfur isotope ratio does not impact the results. Secondly, the persulfate $\delta^{34} S$ value is bounded by the relation $\beta<f$, since in the absence of precipitation and in case of instantaneous decomposition we have $\beta=f$. This leads to a condition of $\delta_{\text {per }}<1 \%$ for $\delta_{a n}=+25 \%$, calculated on sample \#9 (at Cl concentration of $28720 \mathrm{mg} / \mathrm{l}$ ), which is consistent with the measurements on persulfate breaker samples and cores.

As expected, $\beta$ plots below the red curve corresponding to the mixing parameter $f$. This suggests that the decomposition of persulfate is not instantaneous, and that precipitation of sulfate bearing minerals is likely to occur at some point in time. 


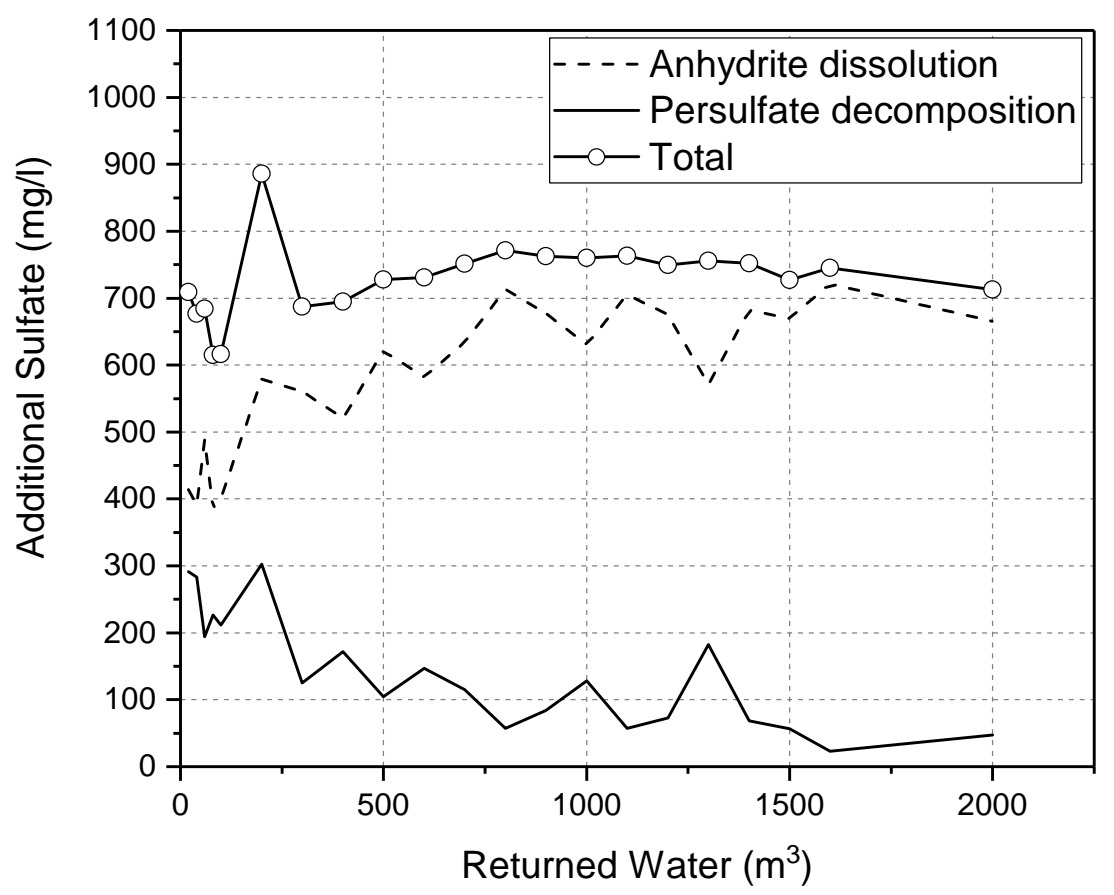

Figure 8: Sources of extra sulfate compared to simple mixing of sulfate in fracturing fluid and sulfate in formation water in the flowback samples as calculated from sulfur isotope ratios of sulfate.

Calculation of the different sulfate contributions from anhydrite, persulfate and pyrite oxidation in each sample is then possible knowing $\beta$. Using equation (4) we can write:

$$
\left[\mathrm{SO}_{4}\right]_{a n}=\left[\mathrm{SO}_{4}\right]_{s p l}-\left[\mathrm{SO}_{4}\right]_{0} f+\left[\mathrm{SO}_{4}\right]_{\infty}(1-f)-\beta[\text { per }]_{0}\left(2+\frac{4}{15} \alpha\right)
$$

It is evident from Figures 4 and 5 that the rapid increase in sulfate concentrations after hydraulic fracturing is accompanied by an increase in $\delta^{34} S$ values of sulfate from $\approx 6 \%$ o to values $>+14 \%$. If the majority of the additional sulfate was derived from sulfate-containing breakers or from pyrite oxidation, a decrease of $\delta^{34} S$ values of sulfate would have been expected. This is not what was observed. The increase in $\delta^{34} S$ values of sulfate clearly revealed that the majority of the additional sulfate was derived from dissolution of anhydrite with a $\delta^{34} S$ of $\approx+25 \%$ o consistent with the measurements on rock core samples.

Results from the model described above quantify the sources of additional sulfate compared to simple mixing of sulfate in fracturing fluid and sulfate in formation water, in the flowback and produced water with respect to time as represented in Figure 8. In the samples from the initial phases of flowback, between 200 and $300 \mathrm{mg} / \mathrm{l}$ of sulfate were derived from the persulfate breaker and $500 \mathrm{mg} / \mathrm{l}$ from anhydrite dissolution. In samples from the next 6 days, the sulfate contribution from persulfate and associated pyrite oxidation progressively decreased to about $50 \mathrm{mg} / \mathrm{l}$, whereas the contribution from anhydrite dissolution increased to about $700 \mathrm{mg} / \mathrm{l}$, further supported by a progressive increase in $\delta^{34} S$ values towards $+24 \%$. Sulfate derived from pyrite oxidation was found to be negligible with a maximum of $4 \mathrm{mg} / \mathrm{l}$ (hence not shown in Figure 8). This reveals that more than $90 \%$ of the extra sulfate in flowback waters one week after hydraulic fracturing was derived from anhydrite dissolution. Figure 5 further shows that anhydrite dissolution remains the predominant source of excess sulfate in produced waters 3 to 45 months after hydraulic fracturing, although it appears that this sulfate source is limited leading to decreasing sulfate concentrations with time through dilution by formation water and potentially some limited BSR. 


\subsection{Precipitation of calcite and sulfate bearing minerals}

In Figure 7, parameter $\beta$ plots below the mixing parameter $f$, revealing that there is less sulfate from persulfate in the flowback samples than simple mixing would suggest. This can be either explained by the delay in persulfate decomposition, or by precipitation of sulfate bearing minerals. Persulfate decomposition and its reaction with guar gum is very fast [43], as most processes involving radicals are. As a result, it can be assumed that after a few hours, all persulfate is completely decomposed into sulfate. Therefore, the only explanation of the discrepancy between $\beta$ and $f$ is the precipitation of sulfate bearing minerals. There are several candidates for this precipitation, such as re-precipitation of anhydrite (or gypsum), precipitation of barite $\left(\mathrm{BaSO}_{4}\right)$ or celestite $\left(\mathrm{SrSO}_{4}\right)$. Figures $9 \mathrm{a}$ and $\mathrm{b}$ show the saturation indices for barite and celestite at three different temperatures, $5^{\circ} \mathrm{C}$ (average surface temperature for this specific location), $95^{\circ} \mathrm{C}$ (average downhole temperature for this well) and $25^{\circ} \mathrm{C}$, calculated with PHREEQC and the Pitzer database [44], from the composition of the different flowback samples. Barite is always supersaturated while celestite is undersaturated at the early stage of flowback and reaches equilibrium in the second half of the first week, suggesting precipitation of barite and celestite (or a solid solution of both minerals). This is further supported by Figures $3 \mathrm{c}$, d revealing that both barium and strontium concentrations plot below the conservative mixing line. Interestingly, barite is still supersaturated (or at equilibrium at $95^{\circ} \mathrm{C}$ ), 14.5 months after hydraulic fracturing occurred. Similarly, celestite is also at saturation for all three temperatures for the last datapoint, suggesting that precipitation could still be occurring even after 14.5 months of flowback and well production. The sustained supersaturation of barite over the 14.5 months may also be explained by the use of scale inhibitors, as they destabilize and prevent precipitation but only up to a certain threshold of supersaturation. This would suggest that the supersaturation of barium reached values high enough to overcome the effect of scale inhibitors.

While Figure 8 reveals that dissolution of anhydrite is the predominant source of excess sulfate in flowback and produced water samples, it is possible that anhydrite or gypsum also reprecipitate in the casing while flowback water flows upward to the surface if temperatures and saturation conditions change from those downhole. The PHREEQC calculation (Figures $9 \mathrm{c}$ and $\mathrm{d}$ ) shows that gypsum is undersaturated at every stage of the flowback while anhydrite reaches saturation (and thus potentially precipitation) after $\mathrm{Cl}$ concentrations reach $30,000 \mathrm{mg} / \mathrm{l}$ at reservoir temperature, approximatively at the same time as celestite.

Anhydrite dissolution and persulfate decomposition/pyrite oxidation have a strong secondary impact on the other minerals and dissolved species present. In particular, the Montney siltstone is composed of $16 \%(\mathrm{w} / \mathrm{w})$ dolomite which can dissolve through the acidification of the solution by the $\mathrm{H}^{+}$ions released during pyrite oxidation (equation (8)) and persulfate attack on guar gum (equation (2)). Figure 3, shows that magnesium and calcium concentrations plot above their respective pure mixing lines, which is compatible with dolomite dissolution.

Finally, Figure 9e shows that calcite is supersaturated for every temperature and significant precipitation of calcite can then be expected at every stage of flowback. This precipitation is due to the common ion effect, with anhydrite dissolution releasing large amounts of $\mathrm{Ca}$, which then precipitate with the available dissolved inorganic carbon [45].

\subsection{Mobilization of trace elements}

Another consequence of the oxidating power of the hydraulic fracturing fluids is the potential release of trace metals, which are included in the pyrite matrix and organic matter. Pyrite is known to co-precipitate with numerous heavy metal traces such as nickel, arsenic and lead among others [46], while organic matter can be linked to elements such as uranium, mercury, copper etc. [47, 48]. A combination of the oxidation of pyrite and organic matter by the persulfate breaker has the potential to release these heavy metals in solution which will increase the potential toxicity of the flowback waters and complicate their recycling $[49,50,51]$. The marked increase of the concentrations of the elements represented in Figure 6 is most likely the result of pyrite and organic matter oxidation, releasing those elements into the flowback water (with the exception of Ti, which is likely a by-product of the Ti-based cross-linker). Once oxidation ceases, formation brine, lower in heavy metals than the initial flowback, will tend to "dilute" the heavy 

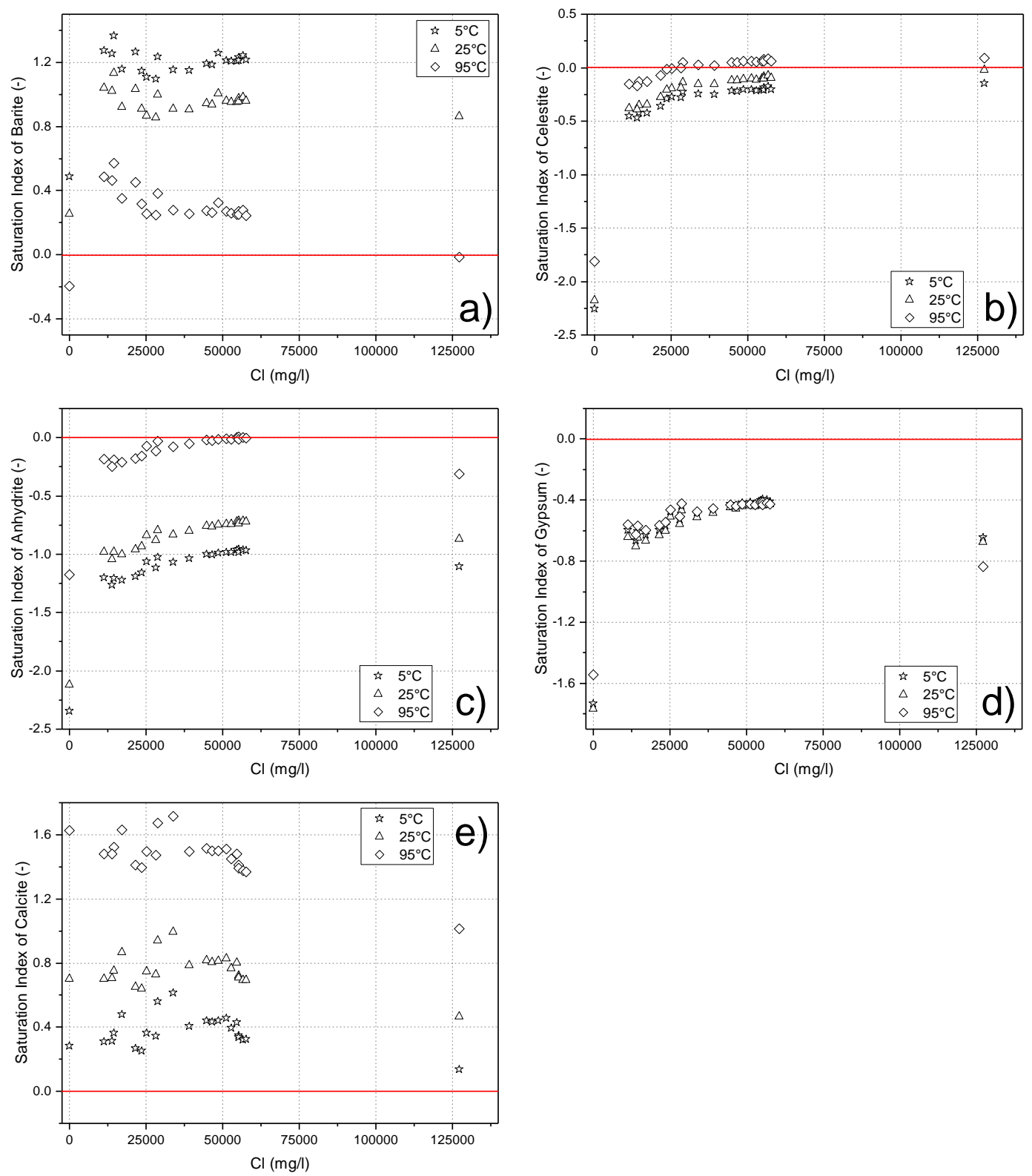

Figure 9: Evolution of the saturation of barite (a), celestite (b), anhydrite (c), gypsum (d) and calcite (e) in the flowback and produced water samples 
metal concentrations. However, the decrease in concentration is faster than just pure mixing. Some authors $[18,52]$ have previously highlighted this behavior and have linked it to the capture of heavy metals during precipitation of iron oxides which is likely to follow pyrite oxidation [53]. This is supported by the non-conservative behavior of iron in Figure $6 \mathrm{~d}$, which appears roughly similar to the behavior of the trace metals and by PHREEQC simulations showing oversaturation for all iron oxi-hydroxides $\left(\mathrm{Fe}(\mathrm{OH})_{2}\right.$, $\mathrm{Fe}(\mathrm{OH})_{3}$, goethite and hematite).

Finally some trace elements Be and V (shown in Figure 6e) do not seem to be linked to a particular oxidation behavior and follow a simple mixing behavior. The most likely explanation for this behavior is that as Be and $\mathrm{V}$ are incompatible elements (i.e. these elements do not easily get incorporated into minerals) $[54,55]$. It is then possible that none of the minerals involved in water-rock interactions contain relevant quantities of these elements, while the precipitation of sulfate-bearing minerals and iron oxi-hydroxides do not impact strongly their concentrations, leading to a somewhat conservative mixing behavior between a V-and Be-poor hydraulic fracturing fluid and a more concentrated formation water.

\subsection{Field implications and conclusion}

The evolution of the different elements in the flowback and produced water samples suggests the following scenarios for the downhole geochemical reactions in the considered well, following hydraulic fracturing. First, within a few hours after injection, a small portion of the oxidative breaker reacts with the host rock pyrite and the organic matter, releasing some sulfate and trace metals. The first returned water has brackish salinity, and slightly elevated contents of sulfate and heavy metals. The release of $\mathrm{H}^{+}$ions by the oxidation reaction triggers the dissolution of dolomite which releases calcium, magnesium and dissolved organic carbon in solution. In the meantime, anhydrite in the formation dissolves while the highly saline formation water flows from the formation toward the hydraulic fractures. The barium and strontium contained in the formation water react with the sulfate released predominantly by anhydrite dissolution and minor persulfate decomposition, and precipitate as barite and celestite (and potentially a solid solution of both), despite the use of scale inhibitors. This precipitation along with the precipitation of iron oxide/hydroxide scavenges the heavy metals released by the oxidative attack of the persulfate limiting their concentration in the flowback samples. Meanwhile, the extra calcium released by both dolomite and anhydrite dissolution triggers calcite precipitation.

After all the persulfate breaker has either reacted or flowed back to the surface, and after the majority of anhydrite has been dissolved, the process halts and reverts to simple mixing between the formation water and the water present in the hydraulic fractures. Sulfate, iron and heavy metals are diluted to the values of the formation water, while $\mathrm{Ca}, \mathrm{Mg}, \mathrm{Ba}$ and $\mathrm{Sr}$ follow a linear evolution with $\mathrm{Cl}$. This dilution of sulfate by the invasion of formation water is further supported by Figures 4 and 5 with the concentrations of constituents in produced waters from the 16 additional wells plotting between the flowback of the first week and the sample 14.5 months later.

All the scenarios described here have important implications for field operations. Geochemical processes such as dissolution, oxidation and scaling may lead to negative consequences on the potential productivity and longevity of the wells [56]. Mineral dissolution is usually a desirable process since it enhances porosity $[57,52]$ and increases the permeability: an increase of a few percent of porosity can increase permeability by several orders of magnitude $[58,59]$. This could be of great importance for the optimization of hydraulic fracturing as an increase of permeability means an improvement of the overall production of gas from the fractures. On the other hand, secondary precipitation of minerals such as anhydrite, calcium carbonate, iron oxides, barite and celestite can have a detrimental effect, by clogging the percolation paths, by decreasing the effective aperture of the hydraulic fractures (proppant grains are very good seeds for mineral precipitation) and by clogging the casing itself. A complete Thermo-Hydro-Chemo-Mechanical (THMC) model seems necessary to grasp all the different processes and for evaluating whether the final outcome of the precipitation/dissolution balance is beneficial or detrimental to the productivity of the well.

Additionally, the release of heavy metals by pyrite and organic matter oxidation is problematic for all the recycling and reuse operations of wastewaters $[4,60]$, especially if these elements include radium. The precipitation of minerals can be a strong asset by trapping the problematic elements downhole. Introducing 
scale inhibitors early (especially for barite), by forcing the precipitation of colloidal particles of barite are a perfect way to both limit the potential danger of barite scaling and trap radium atoms before they reach the surface [61], as radium easily substitutes to barium in barite. Similarly, the precipitation of iron hydroxides should limit the quantity of heavy metals in the flowback water. The toxicity of flowback and produced waters is mostly linked to the very high TDS [51]. However, it can be of interest to compare the quantities of heavy metals in flowback and produced fluids against drinking water standards. For all heavy metals and trace elements detected in the flowback and produced water samples, only $\mathrm{Ni}$ was beyond the World Health Organization guidelines [62] for a short period. The remediation operations should then focus on TDS and organic contaminants [63] as heavy metals do not pose a particular water quality problem.

\section{Acknowledgements}

This research was conducted as part of the G-baseline project, co-funded by the French Research Agency (ANR-14-CE05-0050 grant), the Natural Sciences and Engineering Research Council of Canada (NSERC grant $\left.n^{\circ} 463605\right)$ and TOTAL.

\section{References}

[1] Energy Information Administration (EIA). Annual Energy Outlook 2019 with projections to 2050. 2019.

[2] National Energy Board of Canada. NEB - Canada's Energy Future 2018: Energy Supply and Demand Projections to 2040 - Publication Information and Downloads. Technical report, 2018.

[3] Tanya J. Gallegos and Brian A. Varela. Trends in hydraulic fracturing distributions and treatment fluids, additives, proppants, and water volumes applied to wells drilled in the United States from 1947 through 2010-Data analysis and comparison to the literature. Technical report, US Department of the Interior - US Geological Survey, 2015.

[4] Avner Vengosh, Robert B. Jackson, Nathaniel Warner, Thomas H. Darrah, and Andrew Kondash. A Critical Review of the Risks to Water Resources from Unconventional Shale Gas Development and Hydraulic Fracturing in the United States. Environmental Science E Technology, 48(15):8334-8348, aug 2014.

[5] Andrew J. Kondash, Nancy E. Lauer, and Avner Vengosh. The intensification of the water footprint of hydraulic fracturing. Science Advances, 4(8), 2018.

[6] A.J. Kondash, E. Albright, and A. Vengosh. Quantity of flowback and produced waters from unconventional oil and gas exploration. Science of the Total Environment, 574:314-321, 2017.

[7] M. E. Blauch, R. R. Myers, T. R. Moore, and B. A Lipinski. Marcellus Shale Post-Frac Flowback Waters Where is All the Salt Coming From and What are the Implications? SPE 125740, SPE Regional Eastern Meeting, pages 1-20, 2009.

[8] Lara O. Haluszczak, Arthur W. Rose, and Lee R. Kump. Geochemical evaluation of flowback brine from Marcellus gas wells in Pennsylvania, USA. Applied Geochemistry, 28:55-61, 2013.

[9] Yunyan Ni, Caineng Zou, Huiying Cui, Jian Li, Nancy E. Lauer, Jennifer S. Harkness, Andrew J. Kondash, Rachel M. Coyte, Gary S. Dwyer, Dan Liu, Dazhong Dong, Fengrong Liao, and Avner Vengosh. Origin of Flowback and Produced Waters from Sichuan Basin, China. Environmental Science and Technology, 52(24):14519-14527, 2018.

[10] Elisabeth L. Rowan, Mark A. Engle, Thomas F. Kraemer, Karl T. Schroeder, Richard W. Hammack, and Michael W. Doughten. Geochemical and isotopic evolution of water produced from Middle Devonian Marcellus shale gas wells, Appalachian basin, Pennsylvania. AAPG Bulletin, 99(2):181-206, 2015. 
[11] James Rosenblum, Andrew W. Nelson, Bridger Ruyle, Michael K. Schultz, Joseph N. Ryan, and Karl G. Linden. Temporal characterization of flowback and produced water quality from a hydraulically fractured oil and gas well. Science of the Total Environment, 596-597:369-377, 2017.

[12] Jiemin Lu, Patrick J. Mickler, Jean-Philippe Nicot, Wanjoo Choi, William L. Esch, and Roxana Darvari. Geochemical interactions of shale and brine in autoclave experiments-Understanding mineral reactions during hydraulic fracturing of Marcellus and Eagle Ford Shales. AAPG Bulletin, 101(10):15671597, oct 2017.

[13] Yiman Li, Tianming Huang, Zhonghe Pang, and Chao Jin. Geochemical processes during hydraulic fracturing: a water-rock interaction experiment and field test study. Geosciences Journal, 21(5):753763, 2017.

[14] Thai T. Phan, Amelia N. Paukert Vankeuren, and J. Alexandra Hakala. Role of water-rock interaction in the geochemical evolution of Marcellus Shale produced waters. International Journal of Coal Geology, 191(August 2017):95-111, 2018.

[15] Lin Wang, John D. Fortner, and Daniel E. Giammar. Impact of Water Chemistry on Element Mobilization from Eagle Ford Shale. Environmental Engineering Science, 32(4):310-320, apr 2015.

[16] Mingxiang Xu, Mojtaba Binazadeh, Ashkan Zolfaghari, and Hassan Dehghanpour. Effects of Dissolved Oxygen on Water Imbibition in Gas Shales. Energy and Fuels, 32(4):4695-4704, 2018.

[17] J. K. Pearce, L. Turner, and D. Pandey. Experimental and predicted geochemical shale-water reactions: Roseneath and Murteree shales of the Cooper Basin. International Journal of Coal Geology, 187(September 2017):30-44, 2018.

[18] Virginia Marcon, Craig Joseph, Kimberly E. Carter, Sheila W. Hedges, Christina L. Lopano, George D. Guthrie, and J. Alexandra Hakala. Experimental insights into geochemical changes in hydraulically fractured Marcellus Shale. Applied Geochemistry, 76:36-50, 2017.

[19] Amelia N. Paukert Vankeuren, J. Alexandra Hakala, Karl Jarvis, and Johnathan E. Moore. Mineral Reactions in Shale Gas Reservoirs: Barite Scale Formation from Reusing Produced Water As Hydraulic Fracturing Fluid. Environmental Science and Technology, 51(16):9391-9402, 2017.

[20] Ashkan Zolfaghari, Hassan Dehghanpour, Mike Noel, and Doug Bearinger. Laboratory and field analysis of flowback water from gas shales. Journal of Unconventional Oil and Gas Resources, 14:113-127, 2016.

[21] Victor N. Balashov, Terry Engelder, Xin Gu, Matthew S. Fantle, and Susan L. Brantley. A model describing flowback chemistry changes with time after Marcellus Shale hydraulic fracturing. AAPG Bulletin, 99(1):143-154, 2015.

[22] F. Osselin, M. Nightingale, G. Hearn, W. Kloppmann, E. Gaucher, C. R. Clarkson, and B. Mayer. Quantifying the extent of flowback of hydraulic fracturing fluids using chemical and isotopic tracer approaches. Applied Geochemistry, 93(December 2017):20-29, 2018.

[23] C.D. Rokosh, S.D.A. Anderson, and J.G. Pawlowicz. AER/AGS Special Report 99: QEMSCAN Analysis of Various Lithologies from Tight- and Shale-Gas Plays in Alberta. 2016.

[24] Il Ho Yang and Hyun Suk Lee. Desorbed gas volume estimation using conventional well-log data for the Montney Formation, Deep Basin, Canada. Journal of Petroleum Science and Engineering, 162(June 2017):633-651, 2018.

[25] N. Riazi, C.R. Clarkson, A. Ghanizadeh, A. Vahedian, S. Aquino, and J.M. Wood. Determination of elastic properties of tight rocks from ultrasonic measurements: Examples from the Montney Formation (Alberta, Canada). Fuel, 196:442-457, may 2017. 
[26] C. R. Clarkson, S. M. Ghaderi, M. S. Kanfar, C. S. Iwuoha, P. K. Pedersen, M. Nightingale, M. Shevalier, and B. Mayer. Estimation of fracture height growth in layered tight/shale gas reservoirs using flowback gas rates and compositions-Part II: Field application in a liquid-rich tight reservoir. Journal of Natural Gas Science and Engineering, 36:1031-1049, nov 2016.

[27] A. Ghanizadeh, C.R. Clarkson, S. Aquino, O.H. Ardakani, and H. Sanei. Petrophysical and geomechanical characteristics of Canadian tight oil and liquid-rich gas reservoirs: I. Pore network and permeability characterization. Fuel, 153:664-681, 2015.

[28] Dirk Kirste, Steven Desrocher, Brad Spence, Bill Hoyne, Brian Tsang, and Ian Hutcheon. Fluid flow, water chemistry, gas chemistry and diagenesis in the subsurface Triassic in Alberta and British Columbia. Bulletin of Canadian Petroleum Geology, 45(4):742-764, 1997.

[29] Steven Desrocher, Ian Hutcheon, Dirk Kirste, and Charles M Henderson. Constraints on the generation of $\mathrm{H}_{2} \mathrm{~S}$ and $\mathrm{CO}_{2}$ in the subsurface Triassic, Alberta Basin, Canada. Chemical Geology, 204(3-4):237254, apr 2004.

[30] G.R. Davies, T.F. Moslow, and M.D. Sherwin. The lower triassic Montney Formation, west-central Alberta. Bulletin of Canadian Petroleum Geology, 45(4):474-505, 1997.

[31] Cathy A. Connolly, Lynn M. Walter, H. Baadsgaard, and Fred J. Longstaffe. Origin and Evolution of Formation Waters, Alberta Basin, Western Canada Sedimentary Basin. 1. Chemistry. Applied Geochemistry, 5(4):375-395, 1990.

[32] Cathy A. Connolly, Lynn M. Walter, H. Baadsgaard, and Fred J. Longstaffe. Origin and Evolution of Formation Waters, Alberta Basin, Western Canada Sedimentary Basin .2. Isotope Systematics and Water Mixing. Applied Geochemistry, 5(4):375-395, 1990.

[33] Terry Engelder, Lawrence M. Cathles, and L. Taras Bryndzia. The fate of residual treatment water in gas shale. Journal of Unconventional Oil and Gas Resources, 7:33-48, 2014.

[34] K. S. Sra, J. J. Whitney, N. R. Thomson, and J. F. Barker. Persulfate decomposition kinetics in the presence of aquifer materials. Proceedings of the Annual International Conference on Soils, Sediments, Water and Energy, 12(January):1-10, 2007.

[35] The Environmental Protection Agency. Analysis of Hydraulic Fracturing Fluid Data from the FracFocus Chemical Disclosure Registry 1.0. Technical Report March, U.S. Evironmental Protection Agency - Office of Research and Development, Washington, 2015.

[36] Mastaneh H. Liseroudi, O.H. Ardakani, H. Sanei, P. K. Pedersen, and J.M. Wood. Late sulfate cements in the lower Triassic Montney tight gas play and its relations to the origin of sulfate and H2S. In Abstracts of the 34th annual meeting of the Society of Organic Petrology, Calgary, Alberta, Canada, Calgary, Alberta, Canada, 2017.

[37] James Farquhar, Don E Canfield, Andrew Masterson, Huiming Bao, and David Johnston. Sulfur and oxygen isotope study of sulfate reduction in experiments with natural populations from Fællestrand, Denmark. Geochimica et Cosmochimica Acta, 72(12):2805-2821, jun 2008.

[38] Ramon Aravena and Bernhard Mayer. Isotopes and Processes in the Nitrogen and Sulfur Cycles. In Environmental Isotopes in Biodegradation and Bioremediation, pages 203-246. CRC Press, feb 2010.

[39] George E. Claypool, William T. Holser, Isaac R. Kaplan, Hitoshi Sakai, and Israel Zak. The age curves of sulfur and oxygen isotopes in marine sulfate and their mutual interpretation. Chemical Geology, 28(2003):199-260, 1980. 
[40] B. Mayer. Assessing Sources and Transformations of Sulphate and Nitrate in the Hydrosphere Using Isotope Techniques. In P.K. Aggarwal, J.R. Gat, and K.F. Froehlich, editors, Isotopes in the Water Cycle, pages 67-89. Springer-Verlag, Dordrecht, 2005.

[41] Mark A. Engle and Elisabeth L. Rowan. Geochemical evolution of produced waters from hydraulic fracturing of the Marcellus Shale, northern Appalachian Basin: A multivariate compositional data analysis approach. International Journal of Coal Geology, 126:45-56, 2014.

[42] C.A.J. Appelo and D. Postma. Geochemistry, Groundwater And Pollution, Second Edition. Taylor \& Francis, 2005.

[43] I. M. Kolthoff and I. K. Miller. The Chemistry of Persulfate. I. The Kinetics and Mechanism of the Decomposition of the Persulfate Ion in Aqueous Medium 1. Journal of the American Chemical Society, 73(7):3055-3059, jul 1951.

[44] C. A.J. Appelo. Principles, caveats and improvements in databases for calculating hydrogeochemical reactions in saline waters from 0 to $200^{\circ} \mathrm{C}$ and 1 to 1000atm. Applied Geochemistry, 55:62-71, 2015.

[45] Li Jin, Donald I Siegel, Laura K Lautz, Myron J Mitchell, Dennis E Dahms, and Bernhard Mayer. Calcite precipitation driven by the common ion effect during groundwater - surface-water mixing : A potentially common process in streams with geologic settings containing gypsum. Geological Society of America Bulletin, 2009.

[46] P.K. Abraitis, R.A.D. Pattrick, and D.J. Vaughan. Variations in the compositional, textural and electrical properties of natural pyrite: a review. International Journal of Mineral Processing, 74(1-4):41-59, nov 2004.

[47] Eric C. Gaucher, Jeremy Lerat, Jerome Sterpenich, Regine Mosser-Ruck, and Jacques Pironon. Toxic Metals in Shales: Questions and Methods for a Better Management of Flow-Back Waters. URTeC, 2014.

[48] Jérémy G. Lerat, Jérôme Sterpenich, Régine Mosser-Ruck, Catherine Lorgeoux, Isabelle Bihannic, Claire I. Fialips, Niels H Schovsbo, Jacques Pironon, and Éric C. Gaucher. Metals and radionuclides $(\mathrm{MaR})$ in the Alum Shale of Denmark: Identification of MaR-bearing phases for the better management of hydraulic fracturing waters. Journal of Natural Gas Science and Engineering, 53:139-152, may 2018.

[49] Kelvin B. Gregory, Radisav D. Vidic, and David A. Dzombak. Water management challenges associated with the production of shale gas by hydraulic fracturing. Elements, 7(3):181-186, 2011.

[50] Ronald S. Balaba and Ronald B. Smart. Total arsenic and selenium analysis in Marcellus shale, highsalinity water, and hydrofracture flowback wastewater. Chemosphere, 89(11):1437-1442, 2012.

[51] Yuhe He, Shannon L. Flynn, Erik J. Folkerts, Yifeng Zhang, Dongliang Ruan, Daniel S. Alessi, Jonathan W. Martin, and Greg G. Goss. Chemical and toxicological characterizations of hydraulic fracturing flowback and produced water. Water Research, 114:78-87, 2017.

[52] Anna L. Harrison, Adam D. Jew, Megan K. Dustin, Dana L. Thomas, Claresta M. Joe-Wong, John R. Bargar, Natalie Johnson, Gordon E. Brown, and Katharine Maher. Element release and reaction-induced porosity alteration during shale-hydraulic fracturing fluid interactions. Applied Geochemistry, 82:4762, jul 2017.

[53] Adam D. Jew, Megan K. Dustin, Anna L. Harrison, Claresta M. Joe-Wong, Dana L. Thomas, Katharine Maher, Gordon E. Brown, and John R. Bargar. Impact of Organics and Carbonates on the Oxidation and Precipitation of Iron during Hydraulic Fracturing of Shale. Energy \& Fuels, 31(4):3643-3658, apr 2017. 
[54] J. Vesely, S A Norton, P. Skrivan, V Majer, P. Kram, T. Navratil, and J M Kaste. Environmental Chemistry of Beryllium. Reviews in Mineralogy and Geochemistry, 50(1):291-317, jan 2002.

[55] Edward S Grew. Mineralogy, Petrology and Geochemistry of Beryllium: An Introduction and List of Beryllium Minerals. Reviews in Mineralogy and Geochemistry, 50(1):1-76, jan 2002.

[56] Wayne W. Frenier and Murtaza Ziauddin. Formation, Removal, and Inhibition of Inorganic Scale in the Oilfield Environment. Society of Petroleum Engineers, 2008.

[57] Lixin Jin, Ryan Mathur, Gernot Rother, David Cole, Ekaterina Bazilevskaya, Jennifer Williams, Alex Carone, and Susan Brantley. Evolution of porosity and geochemistry in Marcellus Formation black shale during weathering. Chemical Geology, 356:50-63, 2013.

[58] Piotr Szymczak and Anthony J C Ladd. Reactive-infiltration instabilities in rocks. Part 2. Dissolution of a porous matrix. Journal of Fluid Mechanics, 738:591-630, jan 2014.

[59] Florian Osselin, Pawel Kondratiuk, Agnieszka Budek, Olgierd Cybulski, Piotr Garstecki, and Piotr Szymczak. Microfluidic observation of the onset of reactive infiltration instability in an analog fracture. Geophysical Research Letters, 43(13), 2016.

[60] Gregory P. Thiel and John H. Lienhard. Treating produced water from hydraulic fracturing: Composition effects on scale formation and desalination system selection. Desalination, 346:54-69, 2014.

[61] Julia Scheiber, Andrea Seibt, Johannes Birner, Nicolas Cuenot, Albert Genter, and Wilfried Moeckes. Barite Scale Control at the Soultz-sous-Forêts ( France ) EGS Site. In Thirty-Eighth Workshop on Geothermal Reservoir Engineering, 2014.

[62] World Health Organisation. Guidelines for drinking-water quality: fourth edition incorporating the first addendum. jun 2017.

[63] Tamzin A. Blewett, Perrine L. M. Delompré, Yuhe He, Erik J. Folkerts, Shannon L. Flynn, Daniel S. Alessi, and Greg G. Goss. Sublethal and Reproductive Effects of Acute and Chronic Exposure to Flowback and Produced Water from Hydraulic Fracturing on the Water Flea Daphnia magna. Environmental Science E Technology, 51(5):3032-3039, mar 2017. 